\title{
Phycological flora diversity in a coastal tropical ecosystem in the Northeast of Brazil
}

\author{
S. M. B. Pereira, E. Eskinazi-Leça \& M. F. Oliveira-Carvalho \\ Departamento de Biologia, Programa de Pós-Graduação em Botânica \\ (PPGB) da Universidade Federal Rural de Pernambuco, Brazil
}

\begin{abstract}
The Santa Cruz Channel is located in the Estuarine Complex of Itamaracá, between the coordinates of $7^{\circ} 34^{\prime} 00^{\prime \prime}-7^{\circ} 55^{\prime} 16^{\prime \prime} \mathrm{S}$ and $34^{\circ} 48^{\prime} 48^{\prime \prime}-$ $34^{\circ} 54^{\prime} 24^{\prime \prime} \mathrm{W}$, northeast of Brazil. This channel is one of the most important productive areas of the littoral zone in the Pernambuco State. Due to the important environmental conditions, its phycological flora diversity is represented by 252 species, distributed in 108 Bacillariophyta, 80 Rhodophyta, 19 Phaeophyta and 45 Chlorophyta. Some representatives of economic value are found, such as Hypnea musciformis (Wulfen in Jacquin) J. V. Lamour., Solieria filiformis (Kuetz.) P. W. Gabrielson (carrageenan producers), Gracilariopsis lemaneiformis (Bory) Dawson, Acleto et Foldvik. Hydropuntia caudata (J. Agardh) Gurgel \& Fredericq and H. cornea (J. Agardh) M. J. Wynne (agar producers). Other species, like H. opuntia (L.) J.V. Lamour, have a high ecological role in the reef bottom.

Keywords: microalgae, macroalgae, biodiversity, Bacillariophyta, Chlorophyta, Ochrophyta, Rhodophyta, Santa Cruz channel, Northeast Brazil.
\end{abstract}

\section{Introduction}

The biodiversity comprises not only the morphological variations of the organisms but also its genetic and ecological variations [12]. In the sea is found one of the highest biodiversities of the world that is a function of the algae diversity [10]. When considering the representation of different plant groups in the marine flora in terms of numbers of species, it is important to remember that species vary enormously in number of individuals and in the size of those individuals, and that the number of species described in any one group probably 
depends more on the amount of study that the group has received than on the actual diversity within the group. In the Northeast of Brazil, one of the higher biological diversity areas is the Santa Cruz Channel, located in the littoral of the Pernambuco State, due to the existence of a complex of habitats that promote the settlement of a very diversified fauna and flora [2,14]. The survey of the phycological flora and its distribution in the diverse habitats of the Santa Cruz Channel is the aim of the present paper.

\section{The Santa Cruz Channel}

It is located in the Estuarine Complex of Itamaracá - Pernambuco ( $7^{\circ} 34^{\prime} 00^{\prime}$ ' $7^{\circ} 55^{\prime} 16^{\prime}$ 'S and $34^{\circ} 48^{\prime} 48^{\prime}$ ' $-34^{\circ} 54^{\prime} 24^{\prime}$ ' $\mathrm{W}$ ), fig. 1 , and is distinguished because represents the third estuarine area covered with mangrove, 2,339 ha of the State, functioning as habitat, nursery and spawn place for a variety of economic value species, such as fishes, crustaceans and mollusks. Of all the biomes, the mangrove is one of the most important ecosystems, because it is responsible for a series of products and ecological functions that influence directly the whole area [13].

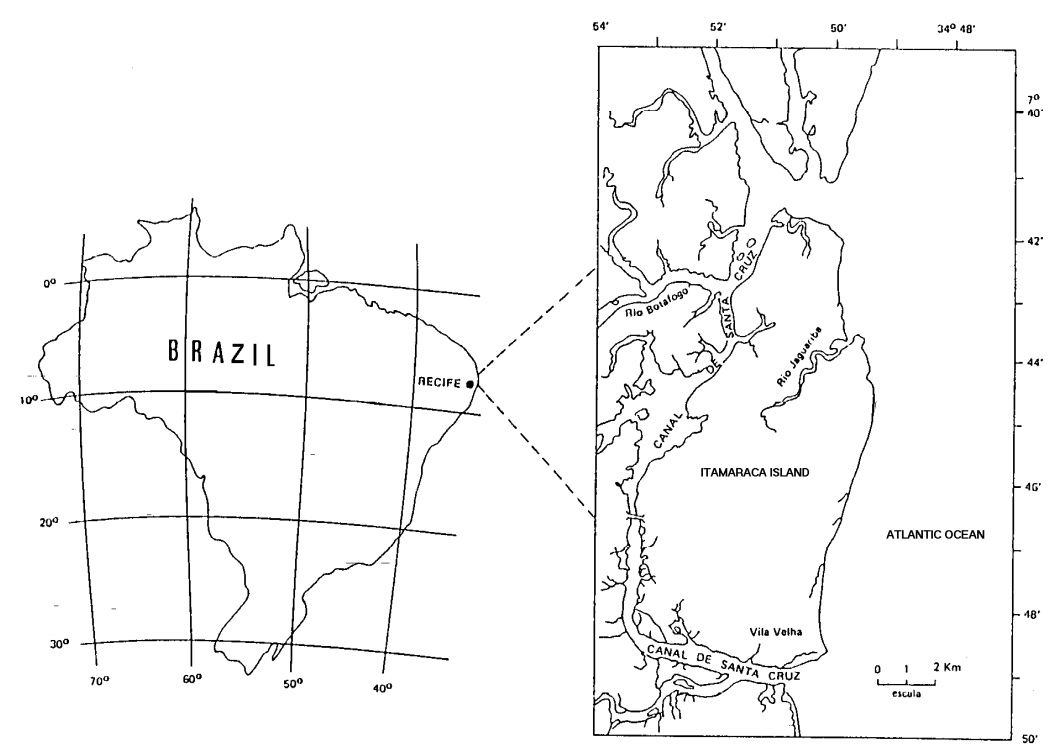

Figure 1: The representative map of the Santa Cruz Channel - Pernambuco Brazil.

The channel acts as a connection between the continent and adjacent marine areas, occurring important physical and chemical mixing processes among them, involving the exportation of dissolved and particulate organic matter produced by the mangroves, and also migrations of juveniles and adults [2]. 
The continental influence in the channel is caused by the arrival of some rivers being responsible for the maintenance of high levels of dissolved nutrients in the water, notably during the rainy season [6]. The salinity of the Santa Cruz Channel is found between the euryhaline-mesohaline regimes (minimum of 14,4 and maximum of 36,9). It occurs due to the constant entrance of marine waters by the two bars of the channel being, thus, the salinity variation directly related to the tide cycles, rivers discharge and pluviometric precipitation [8].

The adjacent continental shelf is plane and narrow, about 20 miles, finishing in an abrupt descending slope that occurs between 60-80 meters. In great part, the bottom is covered with biogenic carbonatic sediments, constituted mainly by fragments of calcareous Rhodophyta, presented under the form of free, branched or crustose thalli, and also by articles of the Chlorophyta Halimeda. The carbonate contents of these sediments are very elevated, always higher than $90 \%$. In the internal continental shelf, the bottom is constituted by quartzose fluvial sand facies, densely settled by the marine phanerogam Halodule wrightii Aschersson, which individuals serve as live substrate for a diversified animal community, as well as for the epiphytic microflora, where the diatoms are distinguished [5]. Another particular aspect of the continental shelf is the presence of the reefs lines, composed of a coralline structure (corals and crustose calcareous algae) established under a sandstone foundation found, mainly, at the depth between 1,5 and 2 meters, also present, however, up to 10 meters depth [5]. These structures represent very favorable substrata to the development of the macroalgae and constitute important elements to the increase of the area productivity $[11,15,17,19]$. The phycological material was collected at various time and locations of the Santa Cruz Channel and adjacent areas.

\section{The phycological flora}

\subsection{Bacillariophyta}

In the Santa Cruz Channel area, the diatoms flora is very diversified, with the species distributed in the following families, tab 1: Biddulphiaceae (16 spp.), Fragilariaceae (15 spp.), Coscinodiscaceae (12 spp.), Naviculaceae (10 spp.), Nitzschiaceae (10 spp.), Chaetoceraceae (09 spp.), Triceratiaceae (08 spp), Rhizosoleniaceae (07 spp.), Surirellaceae (06 spp.), Achnanthaceae (04 spp.), Actinodiscaceae (03 spp.), Eupodiscaceae (03 spp.), Eunotiaceae (03 spp.) and Anaulaceae (02 spp.), tab.1. The floristic structure of the diatoms is characterized by the abundant presence of euryhaline marine species, which correspond to 34 $\%$ of the flora and are found along the channel, in the estuaries and adjacent continental shelf. Among these species, the most representatives are: Bellerochea malleus, Coscinodiscus centralis, Chaetoceros curvisetus, Odontella regia and Skeletonema costatum. The freshwater and estuarine components are little significant and found only during the rainy season, when the continental water flow in the channel is more expressive. 
Table 1: List of the Bacillariophyta species in Santa Cruz Channel Pernambuco - Brazil.

\begin{tabular}{|c|c|}
\hline Bacillariophyta & T. favus Ehrenberg \\
\hline Coscinodiscaceae & T. contortum (Shadbolt) Greville \\
\hline Coscinodiscus asteromphalus Ehrenberg & T. pentacrinus Ehrenberg \\
\hline C. centralis Ehrenberg & T. shadboltianum Greville \\
\hline C. oculusiridis Ehrenberg & Anaulaceae \\
\hline C. radiatus Ehrenberg & Terpsinoe americana (Bailey) Ralfs \\
\hline Cyclotella meneghiniana (Kutz.) Brébisson & Terpsinoe musica Ehrenberg \\
\hline C. stylorum Brigthwell & Fragiliariaceae \\
\hline Melosira moniliformis (Muller) Agardh & Asterionellopsis glacialis (Castracane) Round \\
\hline Paralia sulcata (Ehrenberg) Cleve & Bleakeleya notata (Grunow) Round \\
\hline Skeletonema costatum (Greville) Cleve & Climacosphenia moniligera Ehrenberg \\
\hline Thalassiosira eccentrica (Ehrenberg) Cleve & Fragilaria capucina Desmazieres \& Kutz. \\
\hline T. eccentrica var. fasciculada Hustedt & Grammatophora angulosa Ehrenberg \\
\hline T. leptopus (Grunow) Hasle \& Fryxell & G. hamulifera Kutzing \\
\hline Actinodiscaceae & G. marina (Lyngbye) Kutz. \\
\hline Actinoptychus splendens (Shadbolt)Ralfs & G. oceânica Ehrenberg \\
\hline A. senarius Ehrenberg & Podocystis adriatica Kutzing \\
\hline Stictodiscus parallelus (Ehrenberg) Grove \& Sturt & P. americana (Kutz.) Bailey \\
\hline Eupodiscacceae & Rhabdonema adriaticum Kutzing \\
\hline Actinocyclus ehrenbergii Ralfs & R. mirificum W. Smith \\
\hline Aulacodiscus kittonii Arnot & Striatella unipunctata (Lyngbye) Agardh \\
\hline Eupodiscus radiatus Barley & Thalassionema frauenfeldii Grunow \\
\hline Rhizosoleniaceae & Thalassionema nitzschioides Grunow \\
\hline Guinardia delicatula (Cleve) Hasle & Eunotiaceae \\
\hline Guinardia stolterfothii (Peragallo) Hasle & Eunotia arcus Ehrenberg \\
\hline Leptocylindrus danicus Cleve & E. glacialis Meister \\
\hline Proboscia alata (Bright.) Sundstrom & E. pectinalis (Dyllwyn) Rabenhorst \\
\hline Pseudosolenia calcaravis (Schultze) Sundstron & Achnanthaceae \\
\hline Rhiz. imbricata var. shrubsolei (Cleve) Schroder & Achnanthes brevipes Agardh \\
\hline Rhiz. setigera Brightwell & Campyloneis grevillei (W. Smith) Grunow \\
\hline Chaetoceraceae & Cocconeis scutellum Ehrenberg \\
\hline Bacteriastrum delicatulum Cleve & Raphoneis amphiceros Ehrenberg \\
\hline B. hyalinum Lauder & Naviculaceae \\
\hline Chaetoceros coarctatus Lauder & Anomoeoneis serians (Brebisson) Cleve \\
\hline Chaetoceros compressus Lauder & Caloneis bivittata (Pantocsek) Cleve \\
\hline C. curvisetus Cleve & Diploneis bombus Ehrenberg \\
\hline C. didymu Ehrenberg & D. vacillans (Schmidt) Cleve \\
\hline Chaetoceros laevis Leuduger-Fortmorel & Frustulia rhomboides (Ehrenberg) De Toni \\
\hline C. lorenzianus Grunow & Gyrosigma balticum (Ehrenberg) Rabenhorst \\
\hline C. teres Cleve & Lyrella lyra Ehrenberg \\
\hline Biddulphiaceae & Mastogloia binotata (Grunow) Cleve \\
\hline Bellerochea malleus Brigtwell & M. fimbriata (Brightwell) Cleve \\
\hline Biddulphia biddulphiana Smith & M. splendida (Gregory) Cleve \\
\hline Biddulphia tridens Ehrenberg & Nitzschiaceae \\
\hline Cerataulus smithii Ralfs & Bacilaria paxillifer (Muller) Hendey \\
\hline C. turgidus Ehremberg & Cylindrotheca closterium (Ehrenberg) Reiman \& \\
\hline Ditylum brightwellii (West) Grunow & Lewis \\
\hline Eunotogramma laeve Grunow & Nitzschia circumsuta (Bailey) Grunow \\
\hline Heliotheca thamensis (Shrubsole) Ricard & N. compressa (Bailey) Boyer \\
\hline Hemiaulus indicus Karsten & N. longíssima (Brébisson \& Kutz.) Grunow \\
\hline Isthmia enervis Agardh & N. sigma (Kutzing) Wm. Smith \\
\hline Lithodesmium undulatum Ehrenberg & N. sigmoidea (Nitzsch) Wm Smith \\
\hline Odontella longicruris (Greville) Hoban & N. vermicularis (Kutzing) Hantzsch \\
\hline O. mobiliensis (J.W. Bailey) Grunow & Pseudo-nitzschia pungens (Grunow) Hasle \\
\hline O. regia (Schutz.) Hendey & Tryblionella granulata (Grunow) D. G. Mann \\
\hline Palmeria hardmaniana Greville & Surirellaceae \\
\hline Pleurosira laevis (Ehrenberg) Campère & Campylodiscus biangulatus Greville \\
\hline Triceratiaceae & C. clypeus Ehrenberg \\
\hline Triceratium alltermans Bailey & C. imperialis Greville \\
\hline T. antediluviam (Ehrenberg) Grunow & Petrodictyon gemma (Ehrenberg) D. G. Mann \\
\hline T. broeckii Leuduger-Fortmorel & Surirella fastuosa Ehrenberg \\
\hline T. dubium Brighwell & S. febigerii Lewis \\
\hline
\end{tabular}




\subsection{Rhodophyta}

The Rhodophyta present the higher diversity among the benthic algae, with 80 infra-generic representatives, distributed in 11 Orders, excluding the nonarticulated calcareous algae, tab. 2. Among the Orders, only 3 occur with percentages from 10\%, such as Gigartinales (10\%), Gracilariales $(11 \%)$ and Ceramiales (49\%). The representatives of the other Orders, all together, reach percentages of $29 \%$. Among the Gigartinales, is pointed out the occurrence of species producers of carrageenan such as Hypnea musciformis, Meristotheca echinocarpum and Solieria filiformes. Among the Gracilariales, the high number of species of Gracilaria deserves attention, as well as the important representatives of agar producers, such as Gracilariopsis lemaneiformis and Hydropuntia caudata. In the area, some researches concerning the quantitative aspects of the economic value species have been realized [3, 18]. Among the Ceramiales, Order with higher occurrence percentage, are found the families Ceramiaceae (12 spp.), Dasyaceae (3spp.), Delesseriaceae (1 sp.) and Rhodomelaceae (24 spp.). In this last family, the genus Bostrychia is pointed out with 5 species, occurring in the mangroves of the area, in formations denominated "Bostrychietum". Neosiphonia ferulacea is cited of the first time to Pernambuco State.

\subsection{Ochrophyta}

The lower occurrence percentage among the benthic algae is among the Phaeophyceae. This result was already expected, once these organisms are typical of temperate seas, where they reach a maximum development of its thalli. In the tropical seas, the higher Ochrophyta diversity is found among the Dictyotales and, thus, in the Santa Cruz Channel area they reach the higher occurrence values, with $69 \%$, followed by the Fucales $(26 \%)$ and Ectocarpales $(5 \%)$. In the Brazilian littoral, the higher specific richness of the Dictyotales is found in the northeast, represented mainly by a variety of species of Dictyopteris, Dictyota and Padina. In Itamaracá, this Order is represented by 13 infra-generic taxa, with the best occurrence verified in the genus Dictyota, with 6 representatives, tab. 2 .

\subsection{Chlorophyta}

The Chlorophyta constitute the second higher representation in specific diversity among the marine benthic algae, with 45 infra-generic taxa, classified in the Orders Ulvales, Cladophorales, Bryopsidales and Dasycladales, tab. 2. The higher diversity, at the Order level, is among the Bryopsidales that contribute with $60 \%$ of the total Chlorophyta, followed by the Cladophorales, with $27 \%$. Among the representatives of first Order are found those typical of tropical environments, such as Chamaedoris peniculum, Ventricaria ventricosa and Siphonocladus tropicus. The Ulvales and Dasycladales present the lower occurrence percentages, that is, $9 \%$ and $4 \%$, respectively. Among the 
Table 2: List of the Rhodophyta, Ochrophyta and Chlorophyta species in Santa Cruz Channel - Pernambuco - Brazil.

\begin{tabular}{|c|c|}
\hline Rhodophyta & Chondracanthus acicularis (Roth) Fredericq \\
\hline Stylonematales & Rhizophyllidaceae \\
\hline Stylonemataceae & Ochtodes secundiramea (Mont.) M. Howe \\
\hline Stylonema alsidii (Zanardini) K.M. Drew & Solieriaceae \\
\hline Erythropeltiales & Agardhiella subulata (C.Agardh) Kraft \& M.J. \\
\hline Erythrotrichiaceae & Wynne \\
\hline Erythrotrichia carnea (Dillwyn) J. Agardh & Meristotheca echinocarpum (Aresch.) Faye \& \\
\hline Acrochaetiales & Masuda \\
\hline Acrochaetiaceae & Solieria filiformes (Kutz.) P.W. Gabrielson \\
\hline Acrochaetium agardhiellae A. B. Joly \& Cord.-Mar. & Gracilariales \\
\hline A.hallandicum (Kylin) Hamel & Gracilariaceae \\
\hline A. microscopicum (Nageli ex Kutz.) Nageli & G. cervicornis (Turner) J. Agardh \\
\hline Corallinales & G. cuneata Aresch \\
\hline Corallinaceae & G. domingensis (Kutz.) Sond ex Dickie \\
\hline Pneophyllum fragile Kutz. & G. isabellana Gurgel, Fredericq \& J. N. Norris \\
\hline Corallina oficinalis $\mathrm{L}$. & G. mammillaris (Mont.) M. Howe \\
\hline Jania adhaerens J. V. Lamour. & Gracilaria $\mathrm{sp}$ \\
\hline J. rubens (L.) J. V. Lamour. & Gracilariopsis lemaneiformis (Bory) Dawson, Acleto \\
\hline Amphiroa fragilissima (L.) J. V. Lamour. & et Foldvik \\
\hline A. rigida J. V. Lamour. & Hydropuntia caudata (J. Agardh) Gurgel \& \\
\hline Nemal & Fredericq \\
\hline Galaxauraceae & H. cornea (J. Agardh) M.J. Wynne \\
\hline Dichotomaria marginata (J. Ellis \& Sol.) Lamark. & Halymeniales \\
\hline Galaxaura sp & Halymeniaceae \\
\hline $\begin{array}{l}\text { Tricleocarpa cylindrica (J. Ellis \& Sol.) Huisman \& } \\
\text { Borow }\end{array}$ & $\begin{array}{l}\text { Cryptonemia crenulata (J. Agardh) J. Agardh } \\
\text { Grateloupia cuneifolia J. Agardh }\end{array}$ \\
\hline Scinaiaceae & Halymenia sp \\
\hline Scinaia furcellata (Turner) J. Agardh & Rhodymeniales \\
\hline Bonnemaisoniales & Rhodymeniaceae \\
\hline Bonnemaisoniacae & Botryocladia occidentalis (Borgesen) Kylin \\
\hline Asparagopsis taxiformis (Delile) Trevis. & Champiaceae \\
\hline Cerar & Champia feldmanii Diaz-Pif. \\
\hline Sty & Ochrophyta \\
\hline ceae & tales \\
\hline sidii (Zanardini) K.M. Drew & Dic \\
\hline Eryt & Dictyopteris delicatula J. V. Lamour. \\
\hline Ery & sis W.R. Taylor \\
\hline a carnea (Dillwyn) J. Agardh & D. justii $\mathrm{J}$. \\
\hline Acr & Dicyota bartayresiana J.V. Lamour. \\
\hline Acr & D. cervicornis Kutz. \\
\hline Acrochaetium agardhiellae A. B. Joly \& Cord.-Mar. & D. ciliolata Sond. ex Kutz. \\
\hline A.hallandicum (Kylin) Hamel & D. menstrualis (Hoyt) Schnetter, Hornig \& Weber- \\
\hline picum (Nageli ex Kutz.) Nageli & Peukert \\
\hline Cora & D. mertensii (Mart.) Kutz. \\
\hline Corallinaceae & D. pulchella Hornig \& Schnetter \\
\hline Pneophyllum fragile Kutz. & Lobophora variegata (J. V. Lamour.) Wormersley ex \\
\hline Corallina oficinalis $\mathrm{L}$. & E. C. Oliveira \\
\hline Jania adhaerens J. V. Lamour. & Padina gymnospora (Kutz.) Sond \\
\hline ens (L.) J. V. Lamour. & Padina gymnospora (Kutz.) Sond. \\
\hline Amphiroa fragilissima (L.) J. V. Lamour. & P. santae-crucis Borgesen \\
\hline A. rigida J. V. Lamour. & Spatoglossum schroederi (C. Agardh) Kutz \\
\hline Nemaliales & Chordariaceae \\
\hline Galaxauraceae & Scytosophonaceae \\
\hline Dichotomaria marginata (J. Ellis \& Sol.) Lamark. & Colpomenia sinuosa (Roth) Derbès \& Solier \\
\hline Galaxaura sp & Fucales \\
\hline Tricleocarpa cylindrica (J. Ellis \& Sol.) Huisman \& & Sargassaceae \\
\hline Borov & Sargassum cymosum C. Agardh \\
\hline Scinaiaceae & S. filipendula C. Agardh \\
\hline Scinaia furcellata (Turner) J. Agardh & S. polyceratium Mont. \\
\hline Bonnemaisoniales & S. vulgare var. vulgare C. Agardh \\
\hline Bonnemaisoniacae & S. vulgare var. foliosissimum (J.V. Lamour.) C. \\
\hline Asparagopsis taxiformis (Delile) 7 & Agardh \\
\hline
\end{tabular}


Table 2: $\quad$ Continued.

\begin{tabular}{|c|c|}
\hline Ceramiales & Chlorophyta \\
\hline Ceramiaceae & UlvalesGaylaria oxysperma K.L. Vinogr. ex Scagel \\
\hline Aglaothamnion uruguayense $(W . R$. Taylor $) D$. & et al. \\
\hline Aponte, D. L. Ballant \& J. N. Norris & Ulvaceae \\
\hline Ceramium brevizonatum $\mathrm{H}$. E Petersen & Ulva lactuca L. \\
\hline C. diaphanum (Lightf.) Roth & U. fasciata Delile \\
\hline C. flaccidum (Kutz.) Ardiss. & Ulva $\mathrm{sp}$ \\
\hline C. tenerrimum (G. Martens) Okamura & Cladophorales \\
\hline Crouania attenuata (C. Agardh) C. Agardh & Anadymenaceae \\
\hline Dohrniella antillarum (W. R. Taylor) Feldm.-Mas & Anadyomene stellata (Wulfen in Jacq.) C. Agardh \\
\hline Spermothamnion gymnocarpum $M$. Howe & Cladophoraceae \\
\hline Griffithsia schousboei Mont. & Chaetomorpha aerea (Dillwyn) Kutz. \\
\hline Pleonosporium polystichum E. C. Oliveira & Chaetomorpha sp \\
\hline Spyridia clavata $K u t z$. & Cladophora sp \\
\hline S. filamentosa (Wulfen) Harv. In Hook & Rhizoclonium africanum Kutz. \\
\hline Delesseriaceae & R. riparium (Roth) Kutz. ex Harv. \\
\hline Caloglossa leprieurii (Mont.) G. Martens & Siphonocladaceae \\
\hline Dasyaceae & Chamaedoris peniculum (J. Ellis \& Solander) Kuntze \\
\hline Dictyurus occidentalis J. Agardh & Cladophoropsis membanacea (C. Agardh) Borgesen \\
\hline Heterosiphonia crispella (C. Agardh) M. J. Wynne & Dictyosphaeria cavernosa (Forrsk.) Borgesen \\
\hline H. crispella var. laxa (Borgesen) M. J. Wynne & D. versluysii Weber Bosse \\
\hline Rhodomelaceae & Siphonocladus tropicus (P.Crouan \& Crouan in \\
\hline Acanthophora spicifera (Vahl) Borgesen & Schramm \& Mazé) J. Agardh \\
\hline Amansia multifida J. V. Lamour. & Ventricaria ventricosa (J. Agardh) J. L. Olsen \& J. \\
\hline Bostrychia calliptera (Mont.) Mont. & A. West \\
\hline B. moritziana (Sond ex Kutz.) J. Agardh & Bryopsidales \\
\hline B. radicans (Mont.) Mont in Orbigny & Bryopsidaceae \\
\hline B. scorpioides (Gmelin) Montagne & Bryopsis plumosa (Huds.) C. Agardh \\
\hline B. tenella (J. V. Lamour.) J. Agardh & Derbesia marina (Lyngb.) Solier \\
\hline Bryothamnion seaforthii (Turner) Kutz. & Codiaceae \\
\hline B. triquetrum (S.G. Gmel.) M. Howe & Codium decorticatum (Woodw.) M. Howe \\
\hline Chondrophycus papillosus (C. Agardh) Garbary \& J. & Codium isthmocladum Vickers \\
\hline T. Harper & Caulerpaceae \\
\hline C. perforatus (Bory) K. W. Nam & Caulerpa cupressoides var. lycopodium Weber Bosse \\
\hline Digenea simplex (Wulfen) C. Agardh & C. cupressoides var. lycopodium f. disticha Weber \\
\hline Dipterosiphonia dentritica (C. Agardh) Schmitz in & Bosse \\
\hline Eng. \& Prantl & C. fastigiata Mont. \\
\hline Halopithys schottii (W. R. Taylor) L. E Phillips \& & C. kempfii A B. Joly \& S. M. B. Pereira \\
\hline De Clerck & C. lanuginosa J. Agardh \\
\hline Enantiocladia duperreyi (C. Agardh) Falkenb & C. prolifera (Forssk) J. V. Lamour. \\
\hline Herphosiphonia secunda (C. Agardh) Ambronn & C. prolifera f. obovata (J. Agardh) Weber Bosse \\
\hline Laurencia $s p$ & C. pusilla (Kutzing) J. Agardh \\
\hline Lophosiphonia obscura (C. Agardh) Falkenb. in & C.racemosa var. occidentalis (J. Agardh) Borgesen \\
\hline Engler \& Prantl & C. racemosa var. peltata (J.V.Lamour.) Eubank \\
\hline Murrayella periclados (C. Agardh) F. Schmitz & C. racemosa var. racemosa (Forsskal) J. Agardh \\
\hline Neosiphonia ferulacea (Sur ex J. Agardh) S. M. & C. sertularioides (S.G. Gmel.) M. Howe \\
\hline Guimarães \& M. T. Fujii & C. sertularioides f. brevipes (J. Agardh) Sved. \\
\hline Osmundaria obtusiloba (C. Agardh) R. E. Norris & C. verticillata J. Agardh \\
\hline Polysiphonia denudata (Dillwyn) Grev. Ex Harv. in & Halimedaceae \\
\hline Hook & Halimeda discoidea De \\
\hline P. howei Hollenb. In W. R. taylor & H. incrassata (J. Ellis) J.V. Lamour. \\
\hline P. subtilissima Mont. & H. opuntia (L.) J.V. Lamour. \\
\hline Gelic & H. tuna (J. Ellis \& Sol.) J. V. Lamour \\
\hline Galidiaceae & Udoteaceae \\
\hline Gelidium pusillum (Stach.) Le Jolis & Avrainvillea longicaulis (Kutz.) G. Murray \& Boodle \\
\hline Gelidiellaceae & Boodleopsis pusilla (Collins) W.R. Taylor, A B. Joly \\
\hline Gelidiella acerosa (Forssk.) Feldmann \& Hamel & \& Bernat. \\
\hline Gigartinales & Penicillus capitatus Lam. \\
\hline Caulacanthaceae & Udotea flabellum (J. Ellis \& Sol.) J.V. Lamour \\
\hline Catenella caespitosa (Wither) L.M. Irvine in Parke \& & U. occidentalis A. Gepp \& E. Gepp. \\
\hline Dixon & Dasycladales \\
\hline Cystocloniaceae & Dasycladaceae \\
\hline Hypnea musciformis (Wulfen in Jacqu.) J. V. & Neomeris annulata Dickie \\
\hline Lamour. & Polyphysaceae \\
\hline H.spinella (C. Agardh) Kutz & Acetabularia crenulata J. V. Lamour. \\
\hline Gigartinaceae & \\
\hline
\end{tabular}


Bryopsidales, the most representative families are Caulerpaceae and Udoteaceae, with $32 \%$ and $11 \%$ of occurrence, respectively. The genus Caulerpa, with 7 species, 4 varieties and 3 forms, besides presenting higher diversity among the Chlorophyta, has an important role for the local flora, once some of its representatives, such as Caulerpa cupressoides, C. kempfii, C. prolifera and $C$. racemosa, form extensive meadows in the infra-littoral region, over which develop a varied fauna and flora [4]. Among the genus Halimeda the species $H$. opuntia, forms 20 to $30 \mathrm{~cm}$ high meadows and provides articles to the biodetrital facies [1, 16]. In the mangroves, were identified the cloroficean Gayralia oxysperma, Rhizoclonium africanum and Cladophoropsis membranacea.

\section{Discussion}

The floristic algal diversity in coastal ecosystems depends directly on the action of a variety of environmental factors, which will establish the composition, distribution and variation of the populations. These factors can be chemical, such as the salinity and the nutrients availability; physical, as the luminosity and the nature of the substrata; mechanical, such as the waves and the tides; biological, as the grazing, the parasites and epiphytes action, and the human action itself as destroyer and modifier agent of the environment [7]. In the case of the planktonic microalgae, the physical and chemical factors are the most acting in the development and growing of the populations, mentioning the light, the nutrients availability and the salinity as the most acting. Despite these, the macroalgae also need the presence of suitable substrata.

In the Santa Cruz Channel area, is assumed to have many factors that act in the algae richness and diversity. First, the environmental conditions have to be considered in the area, represented by transparent and nutrient rich waters, essentials for the photosynthesis; second, the habitat diversity, where a variety of substrata is pointed out, such as mangrove roots and steams in the internal area of the channel and reefs lines in the adjacent continental shelf. These factors act together to promote the establishment of different populations, which organisms are distributed according to the circulation patterns, transparency, salinity and occurrence of rocky and motile substrata.

This diversity confirms the ecological importance of the area and intensifies the hypothesis that this place is one of the most productive of the littoral of the State. As a consequence of the phycological diversity, it is natural that also occur a high diversity among the animals, represented by 621 species, constituted by 115 zooplankton species, 134 mollusks, 161 crustaceans, 140 fishes and 71 birds [14]. These animals depend directly on this primary production source, in the various links of the food webs, existing a strong trophic interaction between the phycological flora and the many animals that live in the plankton, benthos and nekton [9]. The ecological characteristics of the phycological flora and its relations with the Santa Cruz Channel and adjacent areas are integrated in a conceptual model presented, fig. 2. 


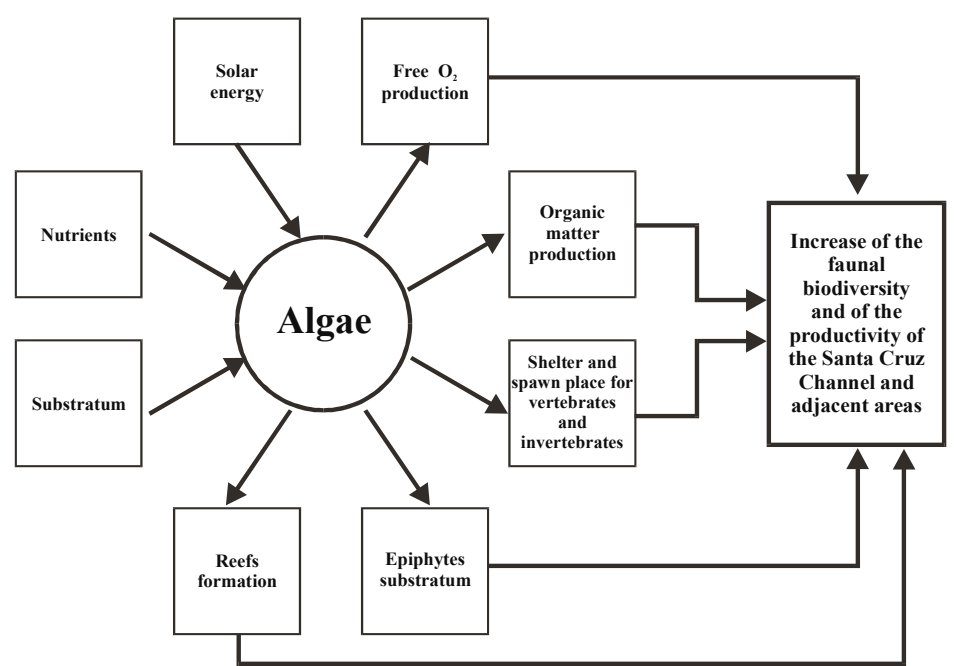

Figure 2: The conceptual model of the Santa Cruz Channel based on ecological characteristics of the phycological flora.

\section{References}

[1] Bandeira-Pedrosa, M.E., Pereira, S.M.B. \& Oliveira, E.C., Taxonomy and distribution of the green algal genus Halimeda (Bryopsidales, Chlorophyta) in Brazil. Revista Brasileira de Botânica, 27 (2), pp. 363377, 2004.

[2] Eskinazi-Leça, E., Barros, H.M. \& Macedo, S.J., Estuarine management in Northeast Brazil: the estuarine complex of Itamaracá (Section 7). Ecosystems and Sustainable Development II, eds. C.A Brebbia \& J.L Uso, WIT Press: Southampton, pp. 246-255, 1999.

[3] Guedes, E.C., Macedo, J.S.\& Pereira, S.M.B., Variação estacional no rendimento de ágar-ágar e carragenano em representantes das Gigartinales (Rhodophyta) no litoral norte do Estado de Pernambuco. Anais da VIII Reunião Nordestina de Botânica, ed. Sociedade de Botânica do Brasil: Recife, pp. 83-98, 1985.

[4] Joly, A.B. \& Pereira, S.M.B., Caulerpa kempfii Joly et Pereira: a new Caulerpa from Northeastern Brazil. Ciência e Cultura, 27, pp. 417-419, 1974.

[5] Kempf, M., Notes on the benthic bionomy of N-NE Brazilian shef. Marine Biology, 5(3), pp. 213-224, 1980.

[6] Koening, M.L. \& Macedo, S.J., Hydrology and phytoplankton community structure at Itamaracá - Pernambuco (Northeast Brazil). Brazilian Archives of Biology and Technology, 42(4), 381-392, 1999.

[7] Lobban, C.S. \& Harrison, P.J., Seaweed ecology and Physiology. Cambridge University Press: New York, pp. 1-366, 1994.

[8] Medeiros, C.; Macedo, S.J.; Feitosa, F.A.N. \& Koening, M.L., Hydrography and phytoplankton biomass and abundance of northeast 
Brazilian waters. Archive of Fishery and Marine Research, 47 (2-3), pp. 133-151,1999.

[9] Neumann-Leitão, S.L. \& Schwamborn, R., Interações tróficas no Canal de Santa Cruz. (Chapter 13). Gerenciamento Participativo de Estuários e Manguezais, eds. H.M Barros, E. Eskinazi-Leça, S.J.Macedo \& T.Lima, Editora Universitária: Recife, pp.163-180, 2000.

[10] Norton, T. A., Melkonian, M. \& Andersen, R., Algal Biodiversity. Phycologia, 35(4), pp. 308-326, 1996.

[11] Oliveira-Carvalho, M.F., Pereira, S. M. B. \& Zickel, C.S. Florística e distribuição espaço-temporal das clorofíceas bentônicas em trechos recifais do litoral norte do estado de Pernambuco - Brasil. Hoehnea, 30(3), pp. 201-212, 2003.

[12] Oliveira, M. C.O., Uso de marcadores moleculares no estudo da biodiversidade. Anais do IV Congresso Latino-Americano de Ficologia, ed. Sociedade Ficológica da América Latina e Caribe: Caxambú, pp.179186, 1998.

[13] Paranaguá, M.N. \& Eskinazi-Leça, E., Ecology of Northeastern Tropical Estuary in Brazil and Technological Perspective in Fishculture. Fish Community Ecology in Estuaries and Coastal Lagoons: Towards and Ecosystem Integration, ed. A. Ýanez-Arancibia, UNAM Press: Mexico (DC), pp. 595-614, 1985.

[14] Paranaguá, M.N., Neumann-Leitão, S., Melo, R.L.S., Coelho, P.A., Vasconcelos, A.L. \& Oliveira, A.M., Management in Northeast Brazil: Faunal Biodiversity. (Section 2). Ecosystems and Sustainable Development II, eds. C.A Brebbia \& J.L Uso, WIT Press: Southampton, pp. 57- 68, 1999.

[15] Pereira, B.M. \& Eskinazi-Leça, E., Estuarine management in Northeast Brazil: Plant Biodiversity (Section 2). Ecosystems and Sustainable Development II, eds. C.A Brebbia \& J.L Uso, WIT Press: Southampton, pp. 70-77, 1999.

[16] Pereira, S.M.B., As algas bentônicas. (Chapter 5). Gerenciamento Participativo de Estuários e Manguezais, eds. H.M Barros, E EskinaziLeça, S.J.Macedo \& T.Lima, Editora Universitária: Recife, pp.49-66, 2000.

[17] Pereira, S.M.B., Oliveira-Carvalho, M.F., Angeiras, J.A.P., BandeiraPedrosa, M.E., Oliveira, N.M.B., Torres, J., Gestinari, L.M.S., Cocentino, A.L.M., Santos, M.D., Nascimento, P.F. \& Cavalcanti, D.R., Algas marinhas bentônicas do Estado de Pernambuco. (Capítulo 5) Diagnostico da Biodiversidade de Pernambuco, orgs. M. Tabarelli \& J.M.C. Silva, Editora Massangan/SECTMA: Recife, 1, pp. 97-124, 2000.

[18] Silva, R.L., Pereira, S.M.B., Oliveira Filho, E.C. \& Eston, V. R. Structure of a bed Gracilaria spp. (Rhodophyta) in Northeastern Brazil. Botanica Marina, 30, pp. 517-523,1987.

[19] Torres, J.; Pereira, S.M.B. \& Yoneshigue-Valentin, Y., Ceramiaceae (Rhodophyta) de áreas recifais do estado de Pernambuco, Brasil. Hoehnea, 31(3), pp. 201-212, 2004. 